\section{Evaluating of Arabic gramer teaching method of education set named Silsiletü'l-Lisan}

\section{Silsiletü'l-Lisan isimli Arapça eğitim setinin dilbilgisi öğretim yöntemi açısından değerlendirilmesi}

\author{
Hacı Yilmaz ${ }^{1}$
}

\begin{abstract}
In recent years, Turkey has become more important than ever in Arabic. In order to be able to read religious texts before, with the knowledge of Arabic, there is a need for qualified personnel who know Arabic in many of the official institutions due to economic, political and cultural reasons. It is not easy for non-Arab societies to acquire these skills. The Turks are a nation that later met with non-Arab Arabic. The relationship of Turks with Arabic dates back centuries. Although Turks never forget their own language, they did not use Turkish as a state language with the influence of Arab culture and civilization. In addition, the Ottomans, not only in the homeland; The school opened its doors to four corners of the empire. In almost every age of our history, Arabic has always found its place in our education system for different reasons, especially for religious reasons.

In this study, the grammar teaching method of ral Silsiletul-Lisan lar which was prepared by the educational institution Arap elLisanu'l-Umm er in the United Arab Emirates, which was taught in private courses and later in the preparatory classes of the university, has been studied in our country since 2013/14. . Set consists of eight books, the first two books sekiz
\end{abstract}

\section{Özet}

Son ylllarda Türkiye'de Arapça her zamankinden daha fazla önem kazanmıştır. Önceleri dinî metinleri okuyabilmek için öğrenilen Arapça, günümüzde ekonomik, siyasi ve kültürel sebeplerden dolayı resmi kurumların birçoğunda aranilan dil haline gelmiştir. Arap olmayan toplumların bu dili öğrenmeleri çok kolay olmamaktadır. Türkler de Arap olmayan ve Arapçayla sonradan tanışan bir millettir. Türklerin Arapça ile olan ilişkisi asırlar öncesine dayanmaktadır. Türkler, kendi dillerini hiçbir zaman unutmasalar da Arap kültür ve medeniyetinin etkisiyle Türkçeyi devlet dili olarak kullanmamışlardır. Ayrıca Osmanlılar, sadece anavatanda değil, imparatorluğun dört bir yanına açtıkları medreselerde de öğretimi Türkçe yerine Arapça olarak yapmışlardır. Tarihimizin hemen her çağında başta dinî olmak üzere değişik nedenlerle Arapça daima eğitim sistemimizin içinde kendisine yer bulmuştur.

Bu çalısma, ülkemizde 2013/14 yıllarından beri önceleri özel kurslarda daha sonraları ise üniversitelerin hazırlık siniflarında okutulan ve Birleşik Arap Emirliklerinde bulunan "elLisanu'l-Umm" adlı eğitim kurumunca hazırlanan "Silsiletul-Lisan" isimli eğitim setinin dilbilgisi öğretim metodu ele alınmıştır. Set, ilk iki kitabı "Başlangıç", üç ve dördüncü kitabı

\footnotetext{
1 Dr. Öğr. Üyesi, Ankara Yıldırım Beyazıt Üniversitesi, İnsan ve Toplum Bilimleri Fakültesi, Doğu Dilleri ve Edebiyatları, Arap Dili ve Edebiyatı Anabilim Dalı, hyilmaz@ybu.edu.tr
} 
Yılmaz, H. (2019). Silsiletü'l-Lisan isimli Arapça eğitim setinin dilbilgisi öğretim yöntemi açısından değerlendirilmesi. Journal of Human Sciences, 16(3), 721-735. doi:10.14687/jhs.v16i3.5715

The Beginning", the third and the fourth book kitab1 Introduction sekiz, the five and sixth books are" Intermediate $\mathrm{c}$, the seven and the eighth books are "Advanced ve.

In the examination, önce Silsiletu'l-Lisan sir Arabic education set has been successful in terms of grammar teaching despite some deficiencies, with the completion of the set, the subjects will be completed, the grammar activities should be increased, the reading pieces should be selected to include the grammar subjects and the basic subjects should be given before the topics In addition, it was concluded that a grammar book may have to be followed in addition to such a set.

Keywords: Silsiletü'l-Lisan Education Set; Grammar Education; Method; Book Review; Book Evaluation.

(Extended English summary is at the end of this document)
"Giriş", beş ve altıncı kitabı "Orta Seviye", yedi ve sekizinci kitabı ise "İleri Düzey" olmak üzere sekiz kitaptan oluşmaktadır.

Yapilan incelemede, "Silsiletu'l-Lisan" Arapça eğitim setinin bazı eksikliklerine rağmen dilbilgisi öğretimi açısından başarılı olduğu, setin bitimiyle beraber konuların tamamlanacağının anlaşıldığı, dilbilgisi etkinliklerinin artırılmasının gerekliliği, okuma parçalarının dilbilgisi konularını içerecek şekilde seçilmesi ve konuların siralamasinda temel konuların daha önce verilmesi gerektiği, aksi taktirde hiç gerek yokken böyle bir sete ek olarak bir dilbilgisi kitabı takip edilmek zorunda kalınabileceği sonuçlarına varılmıştır.

Anahtar Kelimeler: Silsiletü'l-Lisan Eğitim Seti; Gramer Eğitimi; Metot; Kitap İnceleme; Kitap Değerlendirme.

\section{Giriş}

Arap dili, büyük kültür ve medeniyet dili olarak Birleşmiş Milletlerin kabul ettiği diller arasında, dünyada altıncı sırada yer almaktadır. Aslen Arap yarımadasına özgün bir dil olmakla beraber yedinci yüzyıldan itibaren İslamiyet’in yayılmasıyla çok geniş bir coğrafyada kendisine yer bulmuştur. Arap alfabesi, Osmanlı İmparatorluğu dahil, İslam dininin yayıldığı coğrafyada büyük ölçüde benimsenmiş, Latin alfabesinden sonra dünyada yazı dili olarak en çok kullanılan yazı sistemi olmuştur.

Arapçanın önemi İslamiyet'in Arapların dışındaki bölgelere yayılmasıyla birlikte artmış ve bu dinin kutsal kitabının dilinin Arapça olması sadece Türkler için değil, diğer milletleri de bu dili öğrenmeye sevk etmiştir. Bu dilin dünyadaki önemi ve rolünün büyüklüğü sonucunda Birleşmiş Milletler Örgütü 1974 yllında, Arap dilini dünyadaki altıncı resmi dil olarak kabul etmiştir.

Arap dili öğretiminin tarihi, yedinci yüzyılda Orta Doğu'da Arapça konuşmayan toplumlar arasında, İslam'ın yayılmasıyla birlikte başlar. Fakat bu ilk zamanlardaki Arapça öğretiminin nasıl olduğu hakkındaki bilgimiz oldukça sınırlıdır. Çünkü elimizde Arapça öğretimine yönelik olarak bu dönemde hazırlanmış ve günümüze kadar gelmiş bir eser yoktur. Daha sonraki klasik döneme ait dilbilgisi kitapları ise, genel olarak Arapça bilmeyenlere bu dili öğretmeyi amaç edinmemekte, Arap dilinin asıl kullanıcılanı olarak idealize edilmiş Bedevilerin konuşmalarındaki langüistik olguları açıklamayı hedeflemektedir. Klasik döneme ait bu özellik, İslam dünyasındaki Arapça öğretimi geleneğinin 21. yüzyıla kadar uzanan rotasını da belirlemiştir. Batıda ise Arap diline olan ilgi, 9. yüzyılda Doğu Hıristiyanları arasında İslam dinine karşı olan tepki ile bağlantılıdır (Versteegh, 2007: 331).

Türklerin Arapçayla tanışmaları asırlar öncesine dayanmaktadır. Önceleri dinî metinleri okuyabilmek için öğrenilen Arapça, günümüzde ekonomik, siyasi ve kültürel sebeplerden dolay1 resmi kurumların birçoğunda aranılan dil haline gelmiştir. Arap olmayan toplumların bu dili öğrenmeleri çok kolay olmamaktadır. Türkler, kendi dillerini hiçbir zaman unutmasalar da Arap kültür ve medeniyetinin etkisiyle Türkçeyi devlet dili olarak kullanmadılar. Ayrıca Osmanlılar, sadece anavatanda değil; imparatorluğun dört bir yanına açtıkları medreselerde de öğretimi Türkçe yerine 
Yılmaz, H. (2019). Silsiletü’l-Lisan isimli Arapça eğitim setinin dilbilgisi öğretim yöntemi açısından değerlendirilmesi. Journal of Human Sciences, 16(3), 721-735. doi:10.14687/jhs.v16i3.5715

Arapça olarak yapmışlardır. Tarihimizin hemen her çağında başta dinî olmak üzere değişik nedenlerle Arapça daima eğitim sistemimizin içinde kendisine yer bulmuştur. İlk zamanlarda Kuran1 Kerim’i ve dini kitapları anlamak için medreselerde özellikle dilbilgisi ağırlıklı dersler verildi. Y1llarca süren medrese eğitiminde maksat anlamak yerine dilbilgisi olduğundan dilbilgisi kuralları bir kartopu gibi büyüdü, mana ise kar tanesi gibi küçüldü. Denge mana aleyhine bozuldu. İlim öğrenme maksadı dil öğrenmeye, dil öğrenme de dilbilgisi öğrenmeye indirgendi. Dil öğreniminin en iyi metodu bir çocuğun ana dilini edinişine en yakın yöntemle bir dili edinmek idi. Fakat dil dilbilgisi kuralları yığını olarak kodlanınca, bu kodları öğrenip çözmek bir ömre mal olacak bir uğraş haline geldi.Uzun yıllardır medreselerde, medrese hocaları ile modern usul dediğimiz öğretim tekniği arasında ciddi tartışmalar süregelmiştir. Modern usulü benimseyenler, medreselerde takip edilen metodu zaman aşımına uğramış, çağın tekniklerinden uzak bir eğitim anlayışı olarak kabul etmektedirler. Klasik sistemi uygulayanlar ise, İslami ilimlerin daha iyi anlaşılabilmesi için klasik metodun gerekli olduğunu savunmaktadırlar. Klasik sarf-nahiv yöntemiyle dil öğrenecek kadar vakti olmayanlar bu dili öğrenebilmenin yolunun Batılların dil öğrenim yöntemini uygulamak olduğun inandı. O yöntemin taklidiyle yazılan dil öğrenim setleri bir çı̆̆ gibi büyüyerek piyasayı kapladı. Kendi eski yöntemimizi sslah etmeyi düşünen ya hiç olmadı ya da sesleri çok cılız çıkacak kadar az oldu. Bunlara bir de ticaret maksadıyla çıkarılan görsel setler eklenince, Arapça öğrenmek ve öğretmek birkaç ayllk bir iş zannedildi.

Bir yabanc1 dilin öğrenilmesinde şüphesiz en önemli unsur, uygun bir materyalin seçilmiş olmasıdır. Bu konuda ilk sırada elbette kitaplar gelmektedir. Özellikle günümüzde popüler olan eğitim setlerinin okutulması, bu setlerin ne kadar yararlı oldukları konusunda ilgilileri bunlar üzerinde kafa yormaya sevk etmektedir. Bu setlerin gramer bölümleri hedef dilin cümle yapısının ve sözcük yapısının iyi kavranması açısından oldukça önem taşımaktadır. Çünkü bir dilin cümle yapısını ve sözcük bilgisini bilmeden o dilin diğer becerilerinin kazanılması mümkün olmamaktadır. $\mathrm{Bu}$ açıdan ders kitaplarının ve eğitim setlerinin gramer bölümlerinin belli bir yöntemle ve öğrencinin anlayacağı şekilde olması oldukça önem arz etmektedir. Çalışmanın amacı, Türkiye'de her kesimden önemli sayılacak bir öğrenci kitlesine okutulan "Silsiletu'l-Lisan" eğitim setinin gramer eğitimi açısından yeterli olup olmadığını belirleyerek, yeterli olan taraflarını ortaya koymak, yetersiz tarafları varsa bu konuda yapılması gerekenler konusunda önerilerde bulunmaktır. Çalışma "Silsiletu'l-Lisan" eğitim seti ile sinırlı tutulmuştur.

\section{1. İslam Dünyasında ve Türkiye’de Arapça Öğrenimi}

İslam eğitim sisteminde çocukların çoğu okuma-yazma ile Kuran'ı ezbere okumayı öğrendikleri illk eğitim olan, "küttâb" eğitiminden sonra çeşitli hocaların ders halkalarına (halkan) katılarak İslami bilimlerin farklı branşlarında öğrenime devam ederlerdi. Fakat her halükarda mutlaka bir gramercinin derslerine katılırlardı. Çünkü gramer, okuma-yazmanın doğal bir uzantısı olarak bir entelektüelin eğitiminin tabii bir parçasıydı. Bu eğitim herhangi bir hoca tarafindan belirlenmiş bir program olmaksızın çeşitli grup öğrencilere verilen "meclis" tipi bir eğitim olarak adlandırılabilir. İslam dünyasının her yerinde, hatta Arapçanın halkın anadili olmadığı bölgelerde bile, İnsanlar İslami ilimleri mütalaa etmek için bir araya geldiklerinde, eğitim aracı olarak kullanılan dil, mütalaa edilen metinlerin dili olan Arapça olmaktaydı. Bu eğitim sistemi bir kimsenin Batı Afrika'dan Güneydoğu Asya'ya kadar istediği her yerde meşhur alimlerin derslerine katılabilmelerine imkan vermiştir. Çünkü bu dersler, her ne kadar aralarında yöresel dilde yorum ve açıklamalar olsa bile, temelde Arapça olarak verilmiştir. Dolayısıyla Arapça, tıpkı Ortaçağda Latincenin Avrupa'da gördügü fonksiyon gibi İslam ülkelerinde, bilgi ve bilimin "uluslararası dili" olarak fonksiyon görmüştür (Versteegh, 2007: 331-333).

İslam dünyasında görülen başka bir ilginç durum da, Arap olmayan ülkelerde yaşayan ve ana dili Arapça olmayan ancak eğitimini Arapça klasik yöntemle öğrenen alimlerin bu dili öğretme çabaları ve metotlandır. Aslında onların ortaya koyduğu ve bizim medrese eğitimi diye adlandırdığımız yöntem hala devam etmektedir. Bu durum bize, böyle giderse Arapçanın tam anlamıyla ögretilmesi başka bir bahara kaldı cümlesini dilimizden döktürecektir. Çünkü, 
Yılmaz, H. (2019). Silsiletü’l-Lisan isimli Arapça eğitim setinin dilbilgisi öğretim yöntemi açısından değerlendirilmesi. Journal of Human Sciences, 16(3), 721-735. doi:10.14687/jhs.v16i3.5715

konuşmanın özellikle de dinlemenin olmadığı bir program içerisinde Arapçanın hatta hiçbir dilin öğrenilip öğretilemeyeceği kanaatindeyiz.

Son ylllarda gerek dünyada gerekse ülkemizde bu alandaki boşluğu doldurmaya yönelik çabalar ve eğitim materyallerinin çoğaltılması memnuniyet vericidir. Ancak asıl olan bunların eğitim kurumlarında uzman kişilerce öğrencilere aktarılmasıdır. Kanaatimizce bu noktada önemli bir sorunla karşı karşıyayız. Çünkü, Arapça öğretiminin günümüzde istenilen düzeyde olmamasının en büyük nedenlerinden biri, hiç şüphesiz eğitmen sorunudur. Bu sorun makalemizin asıl konusu olmadığından üzerinde fazlaca durulmayacaktır. Ancak bu konuda özellikle öğretmen yetiştiren üniversitelerin ilgili bölümlerine bir hayli iş düşmekte olduğunu söylemenin, mevcut öğretmenleri Arapça çalıştaylar, sempozyumlar ve hizmet içi kurslarla zinde tutmanın mutlak gereklilik olduğunu söylemeden geçemeyeceğiz.

Cumhuriyetin kuruluşundan günümüze kadar geçen dönemde Arapça öğretimi genellikle dinî kurumlarda yürütülmüştür. Orta öğretimde Arapça dersi İmam-Hatip Liselerinde yer almıştır. Bu kurumlar açıldıkları günden bugüne kadar çeşitli aşamalardan geçmiştir. Bu süreçte Arapça öğretimi gerek programda yer alışı gerekse izlenen yöntem açısından, teorik olarak bazı değişikliklere uğrasa da uygulama da çok fazla bir değişiklik olmamıştır. Özellikle bu ders, son dönemlerdeki programlarda amaç noktasında yabancı bir dil olarak kabul edilse de genellikle okulların açıldığı günden bugüne kadar bir meslek dersi olarak kabul edilmiştir. 1984/1985 öğretim yllina kadar, dersler dilbilgisi ayrı metin ayrı bir kitaptan okutulmuş iken, bu öğretim yllından itibaren dilbilgisi ve metin bir arada verilmeye çalışılmıştır. Ancak uygulamada dikkate değer bir gelişme olmamıştır. Çünkü bugüne kadar Arapça dersi sadece bir meslek dersi kabul edilmiştir. Buna paralel olarak, bu ders branş öğretmenleri yerine meslek dersleri öğretmenleri tarafindan yürütülmektedir. Kısacası, bu kurumlarda Arapça öğretimi klasik yöntemlerle yapılmış ve yapılmaya da devam edilmektedir.

\subsection{Modern Dönemde Arapça Öğretimi}

20. yüzyılın ikinci yarısında bağımsızlığını yeniden kazanan Arap dünyasının artan siyasi ve ekonomik önemi nedeniyle, Batılı ülkeler giderek artan oranda "modern Arap dili" uzmanına ihtiyaç duymuştur. Avrupa üniversiteleri bu yeni duruma kendilerini adapte ederek Arapça öğretim programlarında gerekli değişiklikleri yapmışlardır. Ama bu biraz zaman almıştır. Öyle ki, birçok ülkede bu değişim 20. yüzyllın son yirmi yllına kadar gerçekleşememiştir. Avrupa'da Arapça öğretiminin modernleştirilmesi çabaları iki aşamada olmuştur. Önce klasik Arapça öğretiminden modern standart Arapça öğretimine geçilmiş, daha sonra ise âmmîce dersler verilmeye başlanmıştır. Bazı ülkelerde Modern Arapça öğretimine geçiş, oldukça ateşli tartışmalara sebep olmuştur. Klasik Arapçanın filolojik araştırmalarına kendini adamış bazı Arap dili bölümleri, geleneksel bağlarından vazgeçmek istememişlerdir. Bununla beraber, modern zamanların ihtiyaçları onları da netice itibariyle modern standart Arapçaya geçmeye mecbur etmiştir.

Batı Avrupa üniversitelerinde de modern standart Arapça öğretim setleri geliştirilmiştir. Bazı üniversiteler ise, modern standart Arapça öğretimi için yeni metotlar denemişlerdir. 1960'lardan bu yana işgücü olarak bu ülkelere, özellikle Tunus ve Cezayir'den göçmenler gelmiştir. Bu göçmenlerin Avrupa'da kalıcı oldukları anlaşılınca bazı ülkeler onların çocuklarına kendi anadillerinde eğitim verilmesini gerektirecek şekilde kanuni düzenlemeler yapmışlardır. Bu düzenlemelerin asıl amacı onların anadillerini kendilerine öğreterek topluma entegrasyonlarını sağlamaktı. Çünkü bu, bazı bilim adamlarına göre onların ev sahibi ülkenin dillini de öğrenmesini sağlayacaktı. Ama bu amaç ne yazık ki Avrupa ülkelerinin tüm çabalarına rağmen çok az gerçekleşebildi (Versteegh, 2007: 347).

\subsection{Arapça Gramer Tarihine Kısa Bir Bakış}

Nahiv ilmini ilk olarak ortaya çıkaran kişinin Ebu Esved ed-Duelî olduğu söylenirse de gerek İslam aleminde gerekse Batı'daki müsteşriklerin yaptıkları araştırma ve incelemelerde bu ilmin doğuşu ve kurucusu hakkında kesin bir sonuç elde edilememiştir (Bakırcı-Demirayak, 2001. 20). İlk nahiv kitabının kim tarafından yazıldığına dair de kesin bilgiler mevcut olmamakla beraber bazı görüşler ortaya atılmıştır. Örneğin, nahve dair ilk kitabın Abdullah b. Ebî İshak el-Hadramî (ö. 
Yılmaz, H. (2019). Silsiletü’l-Lisan isimli Arapça eğitim setinin dilbilgisi öğretim yöntemi açısından değerlendirilmesi. Journal of Human Sciences, 16(3), 721-735. doi:10.14687/jhs.v16i3.5715

127/745) olması gerektiğini savunan Nihad Çetin, bunun gerekçesini de eldeki mevcut telif eserlerde bu eserden nakiller bulunması şeklinde açıklamaktadır(Çetin,1978: II. 128). Bundan başka bu hususla ilgili daha farklı nakiller de bulunmaktadır (Bakırcı-Demirayak, 2001. 30).

İlerleyen asırlarda Arapça nahiv alimleri, Basra ve Kufe Mektepleri mensupları olarak ikiye ayrılmışlardır. Bu ayrılışın sebebi, Basra Mektebi alimlerinin nahivde halkın kullanış şekillerini esas almaları, Kufelilerin ise, meselelerin çoğunda halkın kullanış biçiminden çok kıyasa başvurmalarından ileri gelmekteydi. Daha sonraları Bağdat, Endülüs ve Mısır Mektepleri de farklı görüşler geliştirerek birer ekol haline gelmişlerdir (Koçak, 1981: 144).

Osmanlilarda Abbasiler ve Emeviler dönemlerindeki kadar ileri derecede olmasa da Türk alimler, en az Arap alimler kadar Arapçaya hakim olarak bu dille ilgili eserler vermişlerdir. Özellikle dilbilgisi alanında yazdıkları eserler dikkate değerdir. Yazdıkları eserlerde Türkçe ve Arapça dillerini kullanan Türk bilginlerinin yazdıkları eserleri M. Sadi Çöğenli“"Eski Harflerle Basılmış Arapça Dil Bilgisi Kitapları Katalogu” ismiyle yayınlamıştır. Bu durum Osmanlılar döneminde Türkler tarafından Arapçaya ne kadar önem verildiğini göstermektedir (Bakırcı-Demirayak, 2001. 158).

Modern dönemde dilbilgisi çalışmaları bambaşka bir boyut kazanmıştır. Klasik dönemlerde Arapçayı öğrenme gayretleri daha çok dinî nedenlere dayanmaktaydı. Modern dönemde artı bu sebepler değişmiştir. Özellikle on sekizinci yüzyıldan itibaren pratik nedenlerden dolayı, Avrupalılar ve özellikle Suriye ve Lübnan'da yaşayan Hıristiyanlar da büyük bir özenle Arap dilini öğrenmeye çalışmışlardır. Bu durum ise, Arapçada ve Arap gramerinde bir takım sorunların yaşanmasına neden olmuştur. Artık bu dilin gramerini öğrenmek isteyen kişi, içinden çıkılamayacak, büyük emek isteyen, uçsuz bucaksız bir denizle karşılaşır hale gelmiştir. Bunun neticesinde grameri kolaylaştırma çalışmaları ortaya çıkmışsa da bu girişimler de başarılı olamamıştır (Bakırcı-Demirayak, 2001. 172).

\subsection{Arapça Gramer Eğitimi}

Dilbilgisi, dili ses, şekil ve cümle yapıları bakımından ele alan ve bunlarla ilgili bütün kuralları belirleyen bilim dalı olarak tanımlanmaktadır. Dilbilgisi öğretimi ise, dilin, ses şekil ve cümle yapılarını bazı yöntemler kullanarak, dili ögrencilere kavratma ve bu sayede onların dili, doğru ve düzgün kullanmalarını hedefleyen etkinlikler yapma işlemidir(Yılmaz, 2018: 2). Dilbilgisine Arapça da Nahiv adı verilir ve terim olarak, "Arapça terkiplerdeki kuralları inceleyen ilim dalı", "cümleleri sağlamlık-bozukluk yönünden inceleyen ilim dalı" (el-Cürcani, ty: 240), "nahiv, Arap sözlerinin anlam ve şekilleri arasındaki ilişkiyi anlayabilmek ve bu yolla anlam ve şekillerini birbirine yaklaştırmak amacıyla, onların kullandıkları bakış açısından bakarak inceleyen bir ilimdir."(elMahtun, 1986: 3).

Dilin temelini oluşturan dilbilgisi öğretiminin asıl amac1, insanın bilinçaltında doğuştan var olan dilbilgisi yapısı ve kurallarını bilinç seviyesine çıkarmak ve bunları bilinçli bir şekilde kullanmalarını sağlamaktır. Bu yüzden dil eğitimindeki yeni yaklaşımlara göre dilbilgisi öğretimi, kural ezberletmek veya teorik bilgi vermek değil, esas amaç sözlü ve yazılı iletişimde bir takım yanlış ve aksaklıkları gidermek için grameri bir araç olarak kullanmaktır (Dolunay, 2010: 277).

İbnü's-Serrâc (ö. 316/928) "Kitâbu'l-Usûl" adlı eserinin ilk cümlesinde, gramer (nahv) yazmaktaki amacının "kişinin onu öğrenerek Arap diline yönelmesi" olduğunu belirtir ve şöyle devam eder: "Gramer, geçmiş alimlerin Arap dilini inceleyerek ortaya koydukları ve böylece bu dili yeni öğrenenlerin son gayelerine ulaştıkları bir ilimdir" (İbnü's-Serrâc, 1985: I, 35).

Arap dili, içerisinde yüzlerce kuralı barındıran zengin bir dildir. Arapçanın "Sarf İlmi," "NahivI" ve "Belagat İlmi" olmak üzere üçlü bir grameri vardır. Arap gramerinin fillin kökü ve çekimleri, isim ve sıfatların meydana getirilişleri, bunların çoğul ve müenneslerinin yapıllşları vb. konularla yani kelimelerin şekilleriyle ilgili olan kısmına ilmu's-Sarf veya İlmu't-Tasrif (kelime bilgisi) denilir. İlmu'n-Nahv ise, cümle bilgisi anlamına gelir (Bakırc1-Demirayak, 2001: 14). Bu gramer sistemi öne alınıp lisan kısmı sonraya bırakıldığında Arapça gerçek anlamıyla öğrenilememektedir. Öğrencinin bu metotla Arapça öğrendiğinde, bir Arap ülkesine gitmek, Araplarla konuşmak, gazete ve dergi okumak, televizyon seyretmek gibi bir hedefi olmadığından kendini geliştirme imkanını hiçbir zaman bulamamaktadır. Bunun sonucunda da çok büyük zaman kaybı olmaktadır. Oysa bir 
Yılmaz, H. (2019). Silsiletü’l-Lisan isimli Arapça eğitim setinin dilbilgisi öğretim yöntemi açısından değerlendirilmesi. Journal of Human Sciences, 16(3), 721-735. doi:10.14687/jhs.v16i3.5715

dilin konuşulması için önce o dili duymak gerekir. Tıpkı bir çocuk gibi. Çocuk, anne ve babasından gördükleri ve duyduklarıyla ana dilini öğrenmektedir. Dikkat edilirse bu süre içinde çocuk, hiç bir şekilde kural ve kaide öğrenmeden kısa bir süre içinde ana dilini öğrenebilmektedir. Bu cümlemizden asla gramer bilgileri öğrenilmesin anlamını çıarılmamalıdır. Gramer bilgileri içerisinde boğulmadan mutlaka temel gramer bilgileri öğrenilmeli, belagat da nahiv kuralları içerisine yedirilmelidir.

\subsection{Konuyla İlgili Yapılan Çalışmalar}

Arapça ders kitaplarının incelenmesi, son yirmi-yirmi beş yıldan beri gündeme gelen bir konudur. Yapılan çalışmaların, doğru materyalin tespiti ve dil becerilerinin öğretimi açısından oldukça faydalı olduğu konusunda herkes hemfikirdir. Bu konuda hemen hemen bu güne kadar Türkiye'de 1992-2017 yılları arasında kullanılan bütün eğitim setleri hakkında lisans üstü çalışmalar yapılmıştır (Özcan vd. 2015: 183). Bizim çalışma konumuzu oluşturan “Silsiletu’l-Lisan” eğitim seti hakkında ise şu ana kadar, Bülent Ecevit Üniversitesi, İlahiyat Fakültesi Dergisi'nde yayımlanan “Arap Dili Eğitiminde Kullanılan Silsiletu'l-Lisan Setinin Öğrenci-Öğretmen Görüşlerine Göre Yöntemsel Açıdan Değerlendirilmesi ve Eksik Yönlerine Çözüm Önerileri” isimli bir tek çalışma yapılmıştır(Özcan, vd.,: 2016). Bu çalışma, Karakuvvetleri Lisan Okulunda, 2013-2014 yılları arasında Arapça öğrenen öğrencilerle öğretmenlerin setin tasarımına, ünitelerine, alıştırmalarına ve dil becerilerine yönelik görüşlerini içermektedir.

\section{Problem}

Türkiye'de uzun yıllar boyunca Arapça dersleri gerek medreselerde gerek İmam Hatip Liselerinde gerekse üniversitelerin ilgili bölümlerinde çoğunlukla gramer ağırlıklı işlenmiştir. $\mathrm{Bu}$ durum artık kısır bir döngüye dönüşmüş ve öğrenci gramer konularına boğdurularak gerçek Arapça öğreniminden mahrum edilmiştir. Burada başta sistem olmak üzere eğitmen ve programların etkisi büyüktür. Son yıllarda, özellikle yaklaşı son on yıldan beri, eğitim kurumlarımızda dört beceriye yönelik yerli ve yabancı Arapça eğitim setleri okutulmaktadır. Bu setlerin sonuncusu Birleşik Arap Emirlikleri'nde bulunan, "el-Lisanu'I-Umm" eğitim kurumunca hazırlanan "Silsiletu'I-Lisan" adlı settir. Bu set, resmi kurumlarda ve özel kurslarda okutulmakta ve öğrencilerin çoğu tarafindan beğenilmektedir. Setin üniteleri işleyiş ve dört beceriyi ne kadar başarıyla verdiği konusunda daha önce bir çalışma yapılmıştır(Özcan vd, : 2015). Ancak yapılan bu çalışmada gramer öğretimi ve metodu üzerinde ayrıntılı bilgi verilmemiş, makalenin asıl amacinın gramer öğretim metodu olmadığından bu konu kısa geçilmiştir. Bu çalışmada söz konusu set, Arapça gramer öğretimi açısından değerlendirecek, bu konuda yeterli olup olmadığı sorusuna cevap aranacak ve gramer eğitiminde setin benimsediği metot detaylı bir şekilde ortaya konulmaya çalışılacaktır.

\section{Yöntem}

Araştırmada nitel "Silsiletu'l-Lisan" eğitim setinin taranması, elde edilen verilen yorumlanması ve gerekli görüldüğü yerlerde önerilerde bulunmak konularına yer verilmiştir.

\subsection{Araştırmanın Modeli}

Eğitim kurumlarında okutulan "Silsileet'ul-Lisan” Arapça eğitim setinin Arapça gramer öğretimi metodu açısından değerlendirilmesini ele alan bu araştırmanın gerçekleştirilmesinde tarama modeli kullanılmıştur. Tarama modeli, geçmişte olmuş ya da halen var olan durumu, var olduğu haliyle betimlemeyi amaçlayan araştırma yaklaşımıdır (Karasar, 1999 : 77).

\subsection{Evren ve Örneklem}

Araştırmanın evrenini, Arapça Eğitimine yönelik yazılmış tüm kitaplar ve eğitim setleri, araştırmanın örneklemini ise, Birleşik Arap Emirliklerinde bulunan "el-Lisanu'I-Umm" isimli eğitim kurumunca hazırlanan "Silsiletu'I-Lisan" adlı set oluşturmaktadır. 
Yılmaz, H. (2019). Silsiletü'l-Lisan isimli Arapça eğitim setinin dilbilgisi öğretim yöntemi açısından değerlendirilmesi. Journal of Human Sciences, 16(3), 721-735. doi:10.14687/jhs.v16i3.5715

\subsection{Verilerin Toplanmas1}

Araştırmada bilgiler, çalışmaya konu olan setin tamamı, özellikler de dilbilgisi konularının anlatıldığ1 bölümler, taranarak elde edilmiştir. Öncelikle konu başlıklarının konu ile olan ilgisine bakılmıştır. Daha sonra teorik bilgilerin veriliş şekilleri ve örneklerin incelenmesine geçilmiştir. Verilerin toplanmasında zaman zaman diğer eğitim setleri ve gramer kitaplarıyla konunun anlatıllş biçiminin karşılaştırılmasına gidilmiştir.

\subsection{Verilerin Analizi}

Elde edilen verilerin analizinde, konunun yeterince ve açık bir dille verilip verilmediğine, seviyeye uygun olup olmadığına bakılmıştır. Ayrıca konular hakkında gerektiği kadar örneklerin verilip verilmediğine ve örneklerin günlük hayattan olup olmadığı kontrol edilmiştir. Bunun yanında dilbilgisi konularıyla okuma parçalarının paralelliği gözlemlenmiştir.

\section{Bulgular ve Değerlendirme}

$\mathrm{Bu}$ bölümde elde edilen verilerin analizine yer verilmiştir. Bulguların analizi aşağıdaki inceleme sırasina göre yapilmıs:

1- Set hakkında genel bilgi,

2-Her ciltte geçen gramer konularının tasnifi,

3-Gramer konularının işlenişi ve öğretim metodu yönünden incelenmesi.

\subsection{Set Hakkında Genel Bilgi}

Türkiye'de Arapça eğitimi, Üniversitelerin Arap Dili ve Edebiyatı, Mütercim Tercümanlık Anabilim Dalları ve İlahiyat Fakültelerinin Arap Dili ve Belağatı Anabilim Dallarında verilmektedir. Bu eğitim kurumlanının bir kısmında hazırlık sınıfları da bulunmaktadır. Hazırlık sınıfı bulunmayan kurumlar "Silsiletu'l-Lisan" isimli eğitim setini birinci sinıfta okuturken hazırlık sinıfi olanlar adı geçen seti bu sinıflarda okutmaktadır. Bahsi geçen her iki kurumda da ülkemizin içinde bulunduğu imkanlar ölçüsünde teknolojik alet ve edevatın kullanıldığı bilinmektedir. Özellikle hazırlık sınıfi olan kurumlarda eğitim bir yıl fazla olmasına karşın, öğrencilerin hazırlık sınıflarındaki Arapçaya karşı olan motivasyonlarının oldukça yüksek olduğunu söyleyebiliriz. Bunun sebeplerinden birisi, hiç şüphesiz bir yabancı dil öğrenme korkusunun büyük ölçüde hazırlık sınıfının ilk aylarında atılmış olmasidir.

Üniversitelerin ilgili bölümleri bu seti okuturken hem ana kitaplardan hem de yardimc1 kitaptan faydalanmaktadır. Setin şu ana kadar bir ve ikinci kitabına ait "Alıştırma Kitabı" ve setin tamamını kapsayan "Öğretmen Kitabı" dışında başka bir yardımcı materyali bulunmaması setin olumsuz yönlerinden birini teşkil etmektedir. Set, bundan önce çıkan setlerde pek rastlanılmayan ve özellikle ülkemizde Arapça öğretiminde büyük bir eksiklik olan interaktif olma özelliğiyle ön plana çıkmaktadır.

Set, ilk iki kitabı "Başlangıç", üç ve dördüncü kitabı "Giriş", beş ve altıncı kitabı "Orta Seviye", yedi ve sekizinci kitabı ise "İleri Düzey" olmak üzere sekiz kitaptan oluşmaktadır. Setin her kitabının arkasında dinleme cd'lerinin bulunması öğrencilerin okudukları parçaları değişik ortamlarda dinleme firsatı sunmaktadır. Üniteler on ana bölümden meydana gelmektedir. Bu bölümler; Konunun başlığ1 ${ }^{1}$, dersin kelimeleri, derste geçen kalıp ifadeler, resimlere bak ve cevapla, dinle ve oku, dinle ve tekrar et, duyduğunu yaz, parça ile ilgili sorulanı cevapla, alıştırmalar, dilbilgisi bölümüdür. Setin çalışma kitabı, sadece 1 ve 2. kitap için hazırlanmıştır. Siyah-beyaz olarak hazırlanan bu çalışma kitabında konular, ünitede geçen kelimeleri ve yapıları pekiştirmek için farklı alıştırma, grafik ve resimlerle desteklenmiştir. Setin dinleme cd'lerinde okuma parçaları, dinle tekrar et, dinle ve yaz bölümleri anadili Arapça olanlar tarafindan seslendirilmiş ve her birine numara verilmiştir. Dinleme bölümleri ders kitabında "kulaklık" sembolü ile gösterilmiştir. Aynı şekilde 
Yılmaz, H. (2019). Silsiletü'l-Lisan isimli Arapça eğitim setinin dilbilgisi öğretim yöntemi açısından değerlendirilmesi. Journal of Human Sciences, 16(3), 721-735. doi:10.14687/jhs.v16i3.5715

çalışma kitabında her ünitede en az iki dinleme parçası bulunmaktadır. Bunların alıştırmalarında öğrenciden dinlediği metin ile ilgili soruları cevaplaması istenmiştir. Öğretmen kitabında da ileri seviye kitaplar hariç dinleme metin alıştırmalarının cevapları verilmiştir. Böylece öğrencinin vereceği cevapların doğrusu ile karşılaştırmak mümkün olmaktadır.

Öğretmen kitabı, setin tamamı için ve sadece 92 sayfa olarak hazırlanmıştır. Bu kitap öğretmenler için bazı teorik bilgileri içermekle beraber öğretmenin setin her aşamasında yararlanabileceği bir tarzda yazılmamıştır. Bu da öğretmenin öğrencileri yeterince ölçmesini engellemektedir. Oysa öğretmenin kitabının her kitap için ayrı ayrı olması, her kitaptaki aktiviteler için öğretmenin uygulayacağ1 yöntemleri içermesi gibi bir takım gereksinimleri bünyesinde bulundurması gerekirdi. Bu haliyle öğretmen kitabı ancak alıştrrmaların cevaplarını vermekten öte geçememektedir.

Setin kitaplarının baskısı güzel ve kaliteli bir kâğıda basılmıştır. Görselleri büyük oranda konuları yansıtmakta olup genellikle elle çizilmiş resimlerden oluşmaktadır. Ciltlerin kalınlığı oldukça ideal olup taşınması çok kolaydır. Kitapların pdfleri sayesinde sınıf ortamında ekrana yansıtma imkânı sunulmuştur.

"Silsiletu’l-Lisan" isimli setin başka bir özelliği de istenildiği zaman piyasada çok rahat bir şekilde bulunabilmesidir. Sekiz ders kitabı, bir çalışma kitabı ve bir öğretmen kitabından oluşan seti bütün kitapçılarda bulmak mümkün olduğu gibi, her bir kitabı çok uygun fiyata almak da mümkündür. Ayrıca setin tamamını da diğer dillerin eğitim setlerinin neredeyse üçte biri fiyatına satın almak imkânı bulunmaktadır. Bu da setin üstün yönlerinden biri olarak görülmelidir.

\subsection{Ciltlere Göre Gramer Konularının Tasnifi}

"Silsiletu'l-Lisan" eğitim setinin dilbilgisi bölümleri, ünitenin tam ortasında ve "lâhız"sembolü altında verilmiştir. Bu dikkat çekici işaretin altında kısa birkaç cümleyle konu açıklanmış ve bir iki örnek verilmiştir. Aşağıda setin tamamının gramer konularının kitaplara göre dağılımları ve isimleri bulunmaktadır.

1. Kitap (Arapçaya Giriş-1)

\begin{tabular}{|l|l|}
\hline 1.Ünite:ed-Damâiru'l-Munfasıla & 8. Ünite: ez-Zemân (Zarf) \\
\hline 29.Ünite: en-Nisbe & 9. Ünite: eş- Şedde \\
\hline 3.Ünite: --- & 10. Ünite: en-Nekira ve'l- Ma'rife \\
\hline 4. Ünite: Harfu'l-Cer & 11. Ünite: --- \\
\hline 5. Ünite: Edevâtu'l-İstifhâm & 12. Ünite: İsmu't-Tafdil \\
\hline 6. Ünite: el-A'dâd(100 e kadar) & 13. Ünite: ----- \\
\hline 7. Ünite: ------ & \\
\hline
\end{tabular}

2. Kitap (Arapçaya Giriş-2)

3.

\begin{tabular}{|l|l|}
\hline 1. Ünite: İsmu'l-İsare & 9. Ünite: ---- \\
\hline 2.Ünite: ---- & 10. Ünite: ---- \\
\hline 3. Ünite: --- & 11. Ünite: -- \\
\hline 4. Ünite: --- & 12. Ünite: -- \\
\hline 5. Ünite: Mülkiyet zamirleri & 13. ünite. --- \\
\hline 6. Ünite: --- & 14. Ünite: -- \\
\hline 7. Ünite: --- & 15.Ünite: Mustakbel (gelecek zaman) \\
\hline 8. Ünite: ---- & \\
\hline
\end{tabular}


Yılmaz, H. (2019). Silsiletü'l-Lisan isimli Arapça eğitim setinin dilbilgisi öğretim yöntemi açısından değerlendirilmesi. Journal of Human Sciences, 16(3), 721-735. doi:10.14687/jhs.v16i3.5715

Kitap (Başlangıç Seviyesi-1)

\begin{tabular}{|l|l|}
\hline 1. Ünite: Kelime ve çeşitleri & 6. Ünite: Müzekker, müennes \\
\hline $\begin{array}{l}\text { 2.Ünite: İsim } \\
\text { Lamu'ş-Şemsiyye ve'l-Kameriyye }\end{array}$ & 7. Ünite: Müfret-Müsenna -Cemi \\
\hline 3.Ünite: Mazi, muzari, emir & 8. Ünite: Alamâtu'l-ism \\
\hline 4. Ünite: Harf & 9. Ünite: Mübteda, Haber \\
\hline $\begin{array}{l}\text { 5. Ünite: Cümle } \\
\text { Harfu'l-Atf (vav) }\end{array}$ & 10. Ünite: fâil , 1-3 arası saylların temyizi \\
\hline
\end{tabular}

4. Kitap (Başlangıç Seviyesi-2)

\begin{tabular}{|l|l|}
\hline $\begin{array}{l}\text { 1. Ünite: Alâmâtu'l-Fi'l } \\
\text { Damairu } 1 \text { fail l muttasıla }\end{array}$ & 6. Ünite: Edevatu'l-İstifhâm \\
\hline 2.Ünite:ed-Dam'iru'l-Munfasıl Mübteda & 7.Ünite: el-Fâil Damirun Muttasıllun \\
\hline 3.Ünite: İsmu'l-̧̇̇âreti'l-Mubtei & 8.Ünite: Mübteda ve haberin özellikleri \\
\hline 4. Ünite: Ba'du Hurûfi'l-Cer & 9. Ünite: Muzafu'n-İleyh \\
\hline 5. Ünite: Mef ûl bih (nesne) & 10. Ünite: İsmu'l-Mevsul \\
\hline
\end{tabular}

\section{Kitap (Orta Seviye-1)}

\begin{tabular}{|l|l|}
\hline 1. Ünite: en-Nekira ve'l-Marife, & 6. Ünite: Cezmu'l-Fi'li'l-Mudâri \\
Ahrufun Tulfezu ve Tuktebu & Cezmu'l-Efâli'l-Hamse, Envâul-Hemze \\
\hline 2.Ünite: Mebni ve Murab & 7. Ünite: Binâu Fi'li'l-Emr \\
İrabu'l-Musenna ve'l-Cem' & Binâu Fi'li'l-Emri'l-Mu'tel \\
Hurufu'l-Atf, el-Bahs fi'l-Mu'cem & Siğatu'l-Emr, Hemzetu Fi'li'l-Emr \\
\hline $\begin{array}{l}\text { 3.Ünite: Binâu'l-Fi'li'l-Mâdî̀ } \\
\text { İttisâlu'l-Damâir bi'l-fi'li'l-Mâdî } \\
\text { Envâu'l-Fi'li'l-Mu'tel }\end{array}$ & $\begin{array}{l}\text { 8. Ünite: Zarfu'z-Zemân, } \\
\text { KavaiduKitâbeti'l-Hemzeti'l-Mutavassita }\end{array}$ \\
\hline $\begin{array}{l}\text { 4. Ünite: Siyâğatu'l-Fi'li'l-Mudâri } \\
\text { I'râbu'l-Fi'li'l-Mudâri ve Binâuhu } \\
\text { Fâilu'l-Fi'li'l-Mudâri }\end{array}$ & $\begin{array}{l}\text { 9. Ünite: } \\
\text { 5. Ünite: Nasbu'l-Fi'li'l-Mudâri } \\
\text { el-Efâlu'l-Hamse }\end{array}$ \\
\hline
\end{tabular}

6. Kitap (Orta Seviye-2)

\begin{tabular}{|c|c|}
\hline $\begin{array}{l}\text { 1. Ünite: el-Efâlu'n-Nâkısa } \\
\text { Uslubu'n-Nefy }\end{array}$ & $\begin{array}{l}\text { 6. Ünite: el-Lâzım ve'l-Mute'addi } \\
\text { Tasrîfu'l-Fi'li'l-Mu'telli'l-Misâl }\end{array}$ \\
\hline $\begin{array}{l}\text { 2.Ünite: İnne ve Ahavâtuhu } \\
\text { Uslûbu't-Tevkîd } \\
\text { El-Hemzetu'l-Mutatarrife }\end{array}$ & $\begin{array}{l}\text { 7. Ünite: Ba'du'l-Efâli'l-Mute'addiye Elleti } \\
\text { Tansibu Mef ûleyn } \\
\text { Tasrîfu'l-Fi'li'l-Mu'tellil-Ecvef }\end{array}$ \\
\hline $\begin{array}{l}\text { 3.Ünite: Uslûbu't-Teşbîh } \\
\text { Hâlâtu'l-fi'li'l-Mu'teli'n-Nâkıs }\end{array}$ & 8. Ünite: Edevâtu'ş-Şarti Ğayri Câzime \\
\hline $\begin{array}{l}\text { 4.Ünite:Esâlîbu't-Teraccî ve't-Temenni ve'l- } \\
\text { İstidrak }\end{array}$ & $\begin{array}{l}\text { 9. Ünite: Edevâtu'ş-Şarti'l-Câzime } \\
\text { Tasrîfu'l-Fi'li'l-Lefifi'l-Makrûn }\end{array}$ \\
\hline 5.Ünite:Tasrîfu'l-Fi'li'l-mu'telli'n-Nâk1s & $\begin{array}{l}\text { 10. Ünite: Hurûfu'l-Atf } \\
\text { Tasrîfu'l-Fi'li'l-Mehmûzi'l-Evvel } \\
\text { Tasrîfu'l-Fi'li'l-Mudâaf }\end{array}$ \\
\hline
\end{tabular}


Yılmaz, H. (2019). Silsiletü'l-Lisan isimli Arapça eğitim setinin dilbilgisi öğretim yöntemi açısından değerlendirilmesi. Journal of Human Sciences, 16(3), 721-735. doi:10.14687/jhs.v16i3.5715

\begin{tabular}{|c|c|}
\hline \multicolumn{2}{|c|}{ 7. Kitap (İleri Seviye-1) } \\
\hline $\begin{array}{l}\text { 1. Ünite: el-Esmâu'l-Hamse } \\
\text { el-Efâlu'l-Mezîde }\end{array}$ & $\begin{array}{l}\text { 6. Ünite: el-İsmu'l-Maksûr ve } \\
\text { İsmu'l-Mankûs } \\
\text { İsmu'l-Fâil veİsmu'l-Mef ûl }\end{array}$ \\
\hline 2.Ünite: el-İsmu'l-Mevsûl & $\begin{array}{l}\text { 7. Ünite: } \\
\text { el-Memnu' mine's-sarf-1,2,3 } \\
\text { Sarfu'l-Memnu' mine's-Sarf }\end{array}$ \\
\hline $\begin{array}{l}\text { 3.Ünite: Sıfat el-Câmid ve'l-Muştak } \\
\text { es-Sıfatu'l-Muşebbehe }\end{array}$ & $\begin{array}{l}\text { 8. Ünite: el-Mef'ûlu'l-Mutlak } \\
\text { Eşheru Masâdiru'l-Fi'li’s-Sulâsi }\end{array}$ \\
\hline $\begin{array}{l}\text { 4. Ünite: el-Hâl } \\
\text { Envâu'l-Hâl } \\
\text { el-Farku beyne's-Sıfa ve'l-Hâl }\end{array}$ & $\begin{array}{l}\text { 9. Ünite:el-Mef ûlu li-Eclih } \\
\text { El-Masdaru's-Sinâi, Masdaru'l- } \\
\text { Merre, Masdaru'l-Hey'e }\end{array}$ \\
\hline $\begin{array}{l}\text { 5. Ünite: el-Fi'lu'l-Mâdi'l-Mebni li'l-Mechul } \\
\text { el-Fi'lu'l-Mudari'i'l-Mebni li'l-Mechul }\end{array}$ & \\
\hline
\end{tabular}

8. Kitap (İleri Seviye-2)

\begin{tabular}{|l|l|}
\hline 1. Ünite: Masâdıru'l-Fi'l Fevka's-Sulâsi & 6. Ünite: en-Nidâ \\
Mevâdı'u Hemzetu'l-Vasl & Et-Tasğîr \\
\hline 2.Ünite: et-Temyiz & 7. Ünite: el-İstisnâ \\
el-Aded ve'l-Ma'dûd & Uslûbu'l-Kasr-1 \\
\hline 3.Ünite: et-Tevkid & 8. Ünite: \\
El-Kasem & et-Takdîm ve't-Te'hîr \\
Uslubu't-Tevkid & Uslûbu'l-Kasr-2 \\
\hline 4. Ünite: el-Bedel & 9. Ünite: \\
El-Kinâye & Uslûbu'l-Medh ve'z-Zem \\
& İsmu'l-Âlet \\
& El-Câmid ve'l-Muştak \\
\hline 5. Ünite:Uslûbu't-Taaccub & \\
İsmu't-Tafdîl & \\
\hline
\end{tabular}

Setteki gramer konularının akışına bakıldığında, Türkiye'deki müfredata uygun hazırlanan gramer kitaplarıyla (Günday- Şahin, 2005: Sarmış, 2005) paralellik göstermemektedir. Örneğin; adı geçen kitaplarda ilk konu "cümle çeşitleri”" iken, bu konuya setin üçüncü kitabının beşinci ünitesinde rastlıyoruz. Ayrıca çalışmanın ilerleyen bölümlerde ayrıntılı olarak değinileceği gibi Türkiye'deki kitaplar gibi konuların ögrretilmesinde acele edilmemiş, hepsi aynı ünite içerisinde verilmemiş tersine konuyu kolaydan zora doğru parça parça anlatma yolu tutulmuştur. Ayrıca yine bir sonraki bölümde ayrıntılı olarak ele alınacağ1 gibi beşinci kitaptan sonra konular çoğalmaya ve ağırlaşmaya başlamaktadır.

\subsection{Gramer Konularının İşlenişi ve Öğretim Metodu Yönünden İncelenmesi}

Dilbilgisi öğretiminin açıkça ya da örtük olarak yapılmasının gerekli olup olmadı̆̆ının tartışıldığı çeşitli dil öğretim yöntem ve ilkeleri bulunmaktadır. Dil öğretim uzmanları, dil öğrenenlerin biçimden ziyade anlama önem vermeleri gerektiği ve anlam çerçevesinde dili kullanmayı öğrenmeleri gerektiğini tartışmaya devam etmektedirler. Diğer taraftan bazı bilim adamlan, dilbilgisel yeterliliğin iletişimsel becerinin bir bileşeni olarak görüldüğü için gramer bilgisinin gerekli olduğu kanaatindedirler. Bir kısım ilim adamları da zaman kaybı ve kafa karıştırıcılığını öne sürerek dilbilgisi eğitimini gereksiz bulmaktadırlar (Yılmaz, 2018: 4).

Arap gramerinin zorluğunun sebebi konusunda, konularının çok oluşu ve karmaşıklığ1 rol oynamakla beraber, sebep yalnızca bu değildir. Zannımızca yüzyıllar boyunca alimlerin bu konularda fazlaca çalışmalar yapıp birbirinden oldukça farklı yorum ve görüşler ortaya atmaları, basit konularda 
Yılmaz, H. (2019). Silsiletü’l-Lisan isimli Arapça eğitim setinin dilbilgisi öğretim yöntemi açısından değerlendirilmesi. Journal of Human Sciences, 16(3), 721-735. doi:10.14687/jhs.v16i3.5715

bile şerhler yapıp gereksiz açıklamalarda bulunmaları da bu gün Arap gramerinin anlaşılması ve öğrenilme zorluğu konusunda önemli rol oynamıştur.

Esasen dilbilgisi öğretimi birçok yapının öğrenciye kazandırılması konusunda zaman kazandırmaktadır. Bir anlamda daha kısa zamanda daha iyi kazanımlar elde etmek demektir. Bu sayede öğrencilere karmaşık gelen yapılar öğrencinin zihninde daha iyi pekişmektedir. Dil öğretiminin amaçlarından biri de hedef dilden anadile tercüme yapabilmektir. Hedef dilde söylenen ya da yazılan bir cümleyi dilbilgisel olarak doğru anlayan kişi ana dile düzgün çeviri yapacaktır. Bu anlamda dilbilgisi eğitimi büyük önem taşımaktadır. Ancak dilbilgisi öğrenirken bir yığın dilbilgisi kuralı ezberlemek yerine dilde aktif olarak kullanılacak kuralların ezberlenmesi en iyi ve en faydalı yol olacaktır. Ayrıca dilbilgisi hedef dilde iletişim ve etkileşim için araç olarak öğretilirse öğrencilere daha fayda sağlayacaktır. Çünkü dilbilgisi trafik işaretlerine benzer. Nasıl ki trafik işaretleri gitmek istediğimiz yere gitmekte bize yardımc1 oluyorsa dilbilgisi de insanın öğrenmeyi amaçladığı yabanc1 dili doğru anlama ve anlatmasına yardımcı olur (Yılmaz, 2018: 5). Dolayısıyla dil öğretilirken, o dilin kurallarını doğru, saf ve duru bir şekilde öğretmek ve kullanımı kolay, günlük hayatta kullanılabilecek yapıların öğretimine daha fazla önem vermek gerekmektedir.

Adı geçen setin dilbilgisi konuları aşağıdaki esaslara göre ele alınmıştır:

1-Konunun işleniş zamanlaması, konunun yeri,

2-Konunun anlaşılır bir şekilde anlatılıp anlatılmadığı,

3-Konunun yeterince anlatılıp anlatılmadığ1,

4-İşlenen konunun anlaşılması için yeterli alıştırmanın verilip verilmediği,

5-İşlenen dilbilgisi kuralının okuma, dinleme ve yazma etkinliklerinde yeterince işlenip işlenmediği.

Çalışmamıza konu olan "Silsiletu'l-Lisan" Arapça eğitim setinde dilbilgisi konuları ünitenin ortalarında verilmiş ve yukarıda da bahsedildiği gibi "Lâhız-Bak!, Dikkat et!" kelimesiyle gösterilmiştir. Set, dilbilgisi konularını kolaydan zora doğru ve basit yapılardan karmaşık yapılara doğru giden bir metotla öğretme yolunu tutmuştur. Tümevarım yönteminin benimsendiği görülen sette, konuların büyük bir kısmının tamamı bir seferde değil, bölüm bölüm anlatılarak özümsenmesi ve anlamanın kolaylaştırılması hedeflenmiştir.

Sette bazı konuların tamamının bir ünitede ayrıntılı olarak işlendiği görülür. Örneğin; setin dördüncü kitabı (Başlangıç seviyesi-1) 'nın beşinci ünitesinde mefûlün bih ele alınmıştur (Abs M., vd., 2013: 49-53). Burada öncelikle mefûlun bih'in tanımı yapılmış ve sonra da son harekesinin mansup olması gerektiği ifade edilmiştir. Hemen arkasından konuyla ilgili üç farklı alıştırma verilmiş, bunların bitiminde konuyla ilgili diğer iki kurala, mefûle ihtiyacı olan ve olmayan fillere geçilmiştir. Bu iki kuralla ilgili iki alıştırmalardan sonra dilbilgisine ara vererek bir okuma parçası konulmuş ve öğrencinin kurallardan sıkılması önlenmiştir. Okuma parçasının arkasından mefûlun bih’in muttasıl bir zamir olabileceği kuralı ve ilgili alıştırmalar verilerek konu tamamlanmıştır. Burada bir öğrencinin bu konuyla ilgili bilmesi gereken hemen hemen her şey anlatılmış ve örneklenmiştir. Setin bundan önceki kitaplarında da bundan sonraki kitaplarında da artık bu konuya bir daha değinilmemiş gerek da kalmamıştır.

Eğitim setinin, bazı konuları da birkaç parçaya bölerek verdiği görülmektedir. Bu durum zannımızca bölünen konuların alt bölümlerinin olmasından ve bu alt bölümlerle ilgili kuralların, verilen kurallar öğrenilip pekiştirildikten sonra öğretilmesi amacından kaynaklanmaktadır. Örneğin; birinci kitabın (Arapçaya Girirş-1) onuncu ünitesinde "marife -nekira" konusu ele alınmıştır (Abs M., vd., 2013: 90). Bu konun en basit anlatımıyla, sadece iki cümleyle başına (ال) takısı gelen isimlerin marife, gelmeyip sonu tenvin olanların ise nekire olacaklan ifade edilmiş ve konuyla ilgili kısa iki alıştırma etkinliği verilmiştir. Aynı konu beşinci kitabın (Orta Seviye-1) birinci ünitesinde tekrar ele alınarak bu sefer, marife çeşitleri işlenmiştir(Abs M., vd., 2013: 6). Ancak ilk kısımda başına (ال) takısı gelerek marife olam ismin sadece cins isimler olduğu söylenmemiştir. Bu ve buna benzer birçok örnek, setin anlatım tekniğinin yeterli olmadı̆̆ ve açılamaların kısa olduğu konusunda bize ciddi ipuçları vermektedir. Setteki konuların parçalanarak anlatılması yönteminin 
Yılmaz, H. (2019). Silsiletü’l-Lisan isimli Arapça eğitim setinin dilbilgisi öğretim yöntemi açısından değerlendirilmesi. Journal of Human Sciences, 16(3), 721-735. doi:10.14687/jhs.v16i3.5715

daha iyi anlaşılması açısından bunlardan birkaç tanesini daha buraya almanın faydalı olacağı kanaatindeyim. Birinci kitap (Arapçaya Giriş-1), beşinci ünitede soru edatlarından sadece هاذا/ هل/ ميف/ماذاذا verilirken (Abs M., vd., 2013: 49) dördüncü kitabın (Başlangıç-2) altıncı ünitesinde (Abs M., vd., 2013: 75-76) birinci kitapta verilen soru edatlarına yenisi ekleyerek, bu edatların başlarına harfi cer birleştiğinde alacakları şekil de (عٌّ) ayrı göstermiştir. Yine, ikinci kitabın (Arapçaya Giriş-2) dokuzuncu ünitesinde, gelecek zamanla ilgili kısa bir bilgi verilirken aynı kitabın on beşinci ünitesinde konu iki okuma parçasıyla desteklenerek tekrar ele alınmıştır. Setin tamamında Sarmal Öğrenme Yaklaşıminın ${ }^{2}$ çok güzel ve başarılı bir şekilde kullanıldı̆̆ı görülmektedir.

Konunun bu şekilde ikiye bölünerek anlatılması öğretim teknikleri açısından olumlu bir yaklaşım olmakla beraber marife çeşitlerinin beşinci kitaba bırakılmasının öğrencinin bu üniteye kadar pekiştirebileceği bir kuralın geciktirilmiş olduğu, bu konunun en azından üçüncü kitapta ele alınmasının daha uygun olacağı kanaatindeyiz.

Setin bazı ünitelerinde, ünite konusu işlenirken dilbilgisi anlamında yeni bir konu verilmemiş, bir önceki dilbilgisi konu pekiştirilmeye çalışılmıstır. Buna örnek olarak birinci kitap (Arapçaya Giriş-1)'in üç, yedi ve sekizinci ünitelerini gösterebiliriz.

Öte yandan bazı konular işlenirken Arapçaya yeni başlayanlar için gerçekten yetersiz sayılabilecek bilgiler verildiği söylenebilir. Örneğin, birinci kitabın (Arapçaya Giriş-1) on üçüncü ünitesinde ismu't-tafdîl konusu işlenirken teorik bilgi çok az verilmiş ve okuma parçalarıyla da desteklenmemiştir. Yine üçüncü kitap (Başlangıç Seviyesi-1)'in altıncı ünitesinde Arap dilinin olmazsa olmazı olan konularından muennes- müzekker konusu hakkında çok az bilgi verilmiş setin ilerleyen kitaplarında da bu konuya bir daha değinilmemiştir. Bunun gibi, beşinci kitap (Orta Seviye1), ikinci ünitede de ikil ve çoğullar hakkında gayet az bilgi verildiği gibi kanaatimizce bu konu da daha önce verilmesi gerekli konular arasındadır. Bunun yanında yeterli ve doyurucu bilgi veren ve öğrencinin zihninde soru işareti bırakmayan dilbilgisi konularının varlığını da göz ardı edemeyiz. Örneğin, üçüncü kitap (Başlangıç Seviyesi-1)' de ikinci ünitede isim-fiil-harf konusunda yeterince bilgi ve alıştırma bulunması öğrencinin bu üç unsurla ilgili bir sorun yaşamamasını sağlamaktadır. Yine üçüncü kitap (Başlangıç Seviyesi-1)'in birinci ünitesinde isim ve fill cümleleri en yalın ve en basit şekliyle anlatularak öğrencinin konuyu kolayca kavraması sağlanmıştır. Öte yandan dördüncü kitap (Başlangıç Seviyesi-2) 'in dördüncü ünitesinde ilk basamağı birinci kitabın dördüncü ünitesinde verilen harfu'l-cerler tam verilerek alıştırmalarla ve okuma parçalarnyla desteklenmiştir. Bu konunun da dördüncü kitaba bırakılması da tarafimızca gecikmiş bir konu olarak görülmektedir. Çünkü harfi cerler bu kitaba kadar oldukça fazla geçmiş ve öğrenci zaten bir şekilde bunları öğrenmiştir. Dolayısıyla set, her ne kadar metot olarak işitsel ağırlıklı bir yol izlemişse de bazı konuların önceden bilinmesi öğrencinin kavrama gücünü artıracağ1 kesindir.

Setin dilbilgisi konularını işleme yöntemi ile ilgili başka bir konu da ele alınan dilbilgisi kuralının o ünitede yeterince işlenip işlenmediği konusudur. Set üzerinde yapılan başka bir çalışmada bu dilbilgisi konularının ünitenin geneline yayıldığı söylense de (Özcan vd. 2015: 195) tespitlerimize göre bu çok doğru bir yaklaşım değildir. İncelemelerimizde genellikle iki okuma parçasının en az birinde bazen ikisinde ve ünite sonlarında "oku ve tekrar et" bölümlerinde, o ünitede işlenen dilbilgisi konusuna hiç değinilmemiştir. Setin genel yapısı hemen hemen aynı şekildedir. Çünkü set sarmal öğretim yaklaşımını benimsediğinden öğrettiği dilbilgisiyle ilgili pratiği daha sonraki ünitelerde yapmaktadır. Örneğin, birinci kitap (Arapçaya Giriş-1) onikinci ünitede ismu’t-tafdil konusu işlenmiş, bir alıştırma aktivitesi verilmekle yetinilmiştir. Ancak her iki okuma parçasında da "dile ve tekrar et" bölümünde de bir kere bile ismu't-tafdil geçmemektedir. Yine ikinci kitap (Arapça Giriş -2), beşinci ünitede mülkiyet zamirlerinin isimlerle kullanılması ele alınmış olmasına

\footnotetext{
${ }^{2}$ Bruner'in 1960'ta ortaya koyduğu sarmal öğrenme yaklaşımı (SPR) öncelikle ana terimleri belirlemek ve düşük zorluk derecesinden daha zor ve karmaşı problemlere geçmeyi temellendirmektedir. Her yeni düzeye geçişte ilk düzeyde öğrenilen kavramlar kullanılmaya ve tekrarlanmaya devam edilmekte; bu bakımdan öğrenme süreci kesintiye uğramamaktadır. Öğrenciyi merkeze alan bu eğitim biçimiyle ögrencinin içindeki merak duygusu beslenmekte; planlama yapması, araştırmacı olması ve bulgularını paylaşarak, uygulamasını temellendiriyor(http://www.akasyam.com/egitimde-sarmal-yaklasim-nedir ?).
} 
Yılmaz, H. (2019). Silsiletü’l-Lisan isimli Arapça eğitim setinin dilbilgisi öğretim yöntemi açısından değerlendirilmesi. Journal of Human Sciences, 16(3), 721-735. doi:10.14687/jhs.v16i3.5715

rağmen iki okuma parçasında da "dile ve tekrar et” bölümünde de bir kere bile bu konuyla ilgili bir örnek bulunmamaktadır.

Bununla birlikte sette anlatulan dilbilgisiyle tamamen ilgili olan okuma parçaları da bulunmaktadır. İkinci kitap (Arapçaya Giriş-2)'nin on beşinci ünitesinde gelecek zaman ele alınmakta ve okuma parçalarında yeterince örnek bulunmaktadır. Bu konuyla ilgili sonuç olarak şunu söyleyebiliriz; setin okuma parçaları ünitede geçen dilbilgisi konusuyla çoğu zaman uyumlu değildir. Sondaki "dinle ve tekrar et" bölümündeki örneklerin ise tamamen ilgisiz olduğu gözlemlenmiştir. Bu bölüm genellikle geçen ünitelerin tekrarını sağlayacak dilbilgisi kurallarının geçtiği örneklerle doludur. Konuların daha iyi anlaşılması daha sonraki ünitelere bırakılmıştır.

\section{Sonuç ve Öneriler}

Seti gramer öğretim metodu ve konuları işleme yöntemi açısından inceledikten sonra ortaya iki sonuç çıkmıştır:

\section{1-Setin dilbilgisi öğretimi açısından olumlu yönleri}

-Konular işlenirken acele edilmemiş, bir iki konu hariç, bir konunun tamamı verilmeden basitten zora doğru bir yol izlenmiştir.

-Sette sarmal öğrenme yaklaşımı metodu benimsenmiş ve tüm set boyunca çokbaşarılı bir şekilde uygulanmıştır.

-İlk kitaplarda anlatılan konuların basitliği göz önüne alınarak fazla alışırma aktiviteleri verilmese de dördüncü kitaptan sonra alıştırma çeşidi önceki kitaplara nispeten artırılmıştır.

-Sette bazı konuların daha iyi bir şekilde özümsenmesi için gerektiğinde birkaç ünite hiç dilbilgisi konusu anlatılmadan geçiştirilmiş, bu ünitelerde geçmiş konuların tekrarı niteliğinde parça okumaları ve diğer aktiviteler yer almıştır.

-Özellikle fiil çekimleri konusunda acele edilmeden mazi, muzari ve emir fillerinin tam çekimlerinin yapılması tüm sete yayılmıştır.

-Özellikle dördüncü kitaptan sonra işlenen dilbilgisi kurallarının pratiğe dökülmesi için cümle iraplarına yer verilmiştir.

- Alıştırmaların çeşitliliği bakımından bakıldığında ilk dört kitapta daha az ve daha kısa alıştırma etkinlikleri yer alırken bundan sonraki kitaplarda, boşluk doldurma, çoktan seçmeli, alı çizili kelimeleri irabının yapılması, tablodaki boş yerleri doldurma, altı çizili kelimeyi istenilen kuralara göre değiştirme, cümleleri irab etme, cümledeki gramer hatasını düzeltme ve dilbilgisi konusuyla ilgili bir paragraf veya parça yazmak gibi çok farklı alıștırmalara yer almaktadır. Bu da konuların anlaşılması açısından oldukça önemlidir.

\section{2-Setin dilbilgisi öğretimi açısından olumsuz yönleri}

-Daha setin ilk kitabında öğrencilerin bilgilerinin az ya da hiç olmadığı konularla ilgili örneklerin verilmesi.

-Kelime çeşitleri ve müzekker-müennes gibi temel konuların setin ilerleyen kitaplarında gecikmeli olarak verilmesi.

-Daha ileride öğretilecek konuların, öğrenciye göz ve kulak alışkanlı̆̆ı için bile olsa, önceden verilmesi öğrenciyi şaşkınlığa, öğretmeni ise gereksiz ve zamansız açıklama yapma zorunluluğuna itmektedir.

-Dilbilgisi konularının özellikle okuma parçalarında yeterince kullanılmaması konunun anlaşılmasını geciktirmektedir.

-Alıştırma çeşidi ve sayısı dördüncü kitaptan sonra belirdin bir artış kaydetse de yine de yeterli değildir. Bu konuda daha önce yapılan çalışmadaki bir anket sonucunda "Yeterince dilbilgisi etkinliğine yer verilmektedir" sorusuna ankete katılan öğrencilerin $\% 56$ kesinlikle katıllyorum, \%7 katıllyorum, $\% 27$ kararsızım, $\% 10$ ise katılmıyorum, diye cevap vermiştir. Buradan da setteki 
Yılmaz, H. (2019). Silsiletü'l-Lisan isimli Arapça eğitim setinin dilbilgisi öğretim yöntemi açısından değerlendirilmesi. Journal of Human Sciences, 16(3), 721-735. doi:10.14687/jhs.v16i3.5715

dilbilgisi etkinliklerinin gözden geçirilmesi gerektiği anlaşılmaktadır (Özcan vd. 2015: 190), denilmektedir.

Sonuç olarak, "Silsiletu'l-Lisan" Arapça eğitim seti bazı eksikliklerine rağmen dilbilgisi öğretimi açısından, özellikle sarmal öğrenme yaklaşımını başarılı ve etkili bir şekilde kullanmasıyla, öne çıkmaktadır. Setteki konuların kavranmasında işitsel metot yani önce bir konuyla ilgili örneklerin birkaç kez önceden parçalarda kullanılması ve daha sonra kural olarak getirilmesi metodu kullanılmıştır. Bu açıdan bu seti okuyan birinin sabırla seti takip etmesi ve setin bitimiyle beraber konuların tamamlanacağını bilmesi gerekir. Çünkü setin hazırlanmasında, özelden genele ya da olaylardan yasalara geçiş şeklindeki, akıl yürütmek anlamına gelen tümevarım yöntemi benimsenmiştir. Konuların çoğunun az ama öz ve anlaşılır bir şekilde anlatılması setin olumlu taraflarındandir.

Kanaatimizce dilbilgisi etkinliklerinin artırılması, okuma parçalarının dilbilgisi konularını içerecek şekilde seçilmesi, konuların sıralamasında temel konuların daha önce verilmesi gibi noktaların göz önünde bulundurulması setin daha başarılı olmasını sağlayacaktır. Aksi takdirde hiç gerek yokken, böyle bir sete ek olarak bir gramer kitabı takip edilmek zorunda kalınabilir ya da öğretmenlere büyük bir yük yüklenmiş olur.

\section{Kaynakça}

Abs, M., es-Sibai, A. el-Ebraş, M., el-Annan, M. (2013). Silliletu'l-Lisan. İstanbul. Fatih Sultan Mehmet Üniversitesi Vakıf Üniversitesi Yayınları.

Bakırc1, S. - Demirayak, K., (2001). Arap Dili Gramer Taribi. Erzurum. Atatürk Üniversitesi Fen Edebiyat Fakültesi Yayını.

Dolunay, S. K., (2010). Dil Bilgisi Öğretiminin Amac1 ve Önemi, TÜBAR-XXVII-/-Bahar, 2010, s. 275-284.

el-Cürcani, eş-Şerif, A. M.,(ty). Tarifat, Kahire, yy.

el-Mahtun, M. B., (1986). el-Musterfa fi'n-Nahv, Tahkikli Metin, Kahire.

Güler, İ., (2004). Dil Öğretimi, Dilbilgisi ve Arapça. Uludağ Üniversitesi Illâhiyat Fakülttesi Dergisi. Cilt: 13, S. 2, s. $169-182$.

Günday, H. - Şahin Ş., (2005). Arapsa Dilbilgisi, Nabiv Bilgisi. İstanbul. Alfa Yayınları.

GündüzÖz, S., (2010). Arapça Öğretiminde Başvurulacak Bazı Yöntem ve Teknikler Pedagojik Bir Değerlendirme. Ondokuz Mayıs Üniversitesi İlabiyat Fakültesi Dergisi. Say1: 29, s.35-53.

İbnü's-Serrâc, (1985). el-Uşû́l fi'n-Nahv. Beyrût. Müessesetü'r-Risâle.

Karasar, N. (1999). Bilimsel Arasstrma Yöntemi.Ankara. Nobel Yayınları.

Koçak, İ., (198). Basra Kufe Mektepleri, A.Ü. DTCF Doğu Dilleri Dergisi, C.II S 4., s.143-155.

Özcan, M. vd. (2016). Arap Dili Eğitiminde kullanılan Silsiletu'l-Lisan Setinin Öğrenci-Öğretmen Görüşlerine Göre Yöntemsel Açıdan Değerlendirilmesi ve Eksik Yönlerine Çözüm Önerileri. Bülent Ecevit Üniversitesi İlabiyat Fakültesi Dergisi, Cilt 3, Say1 1, ss. 181-204

Sarmış, İ., (2005). Arap̧̣a Dilbilgisi. Konya. Esra Yayınları.

Versteegh, K., (2007). Arap Dili Öğretiminin Tarihçesi. Çev: Muhammet Günaydın. İstanbul Üniversitesi Ilahiyat Fakëlltesi Dergisi, Say1: 16, s. 331-353.

Yllmaz, H. (2018). Arap̧̧a Eğitiminde Gramerin Yeri ve Önemi. Sosyal Bilimlerde Yeni Yönelimler-V Sempozyum Bildiri Kitabi. İnstutut za Geografiju

\section{Extended English Summary}

In recent years, Turkey has become more important than ever in Arabic. In order to be able to read religious texts before, with the knowledge of Arabic, there is a need for qualified personnel who know Arabic in many of the official institutions due to economic, political and cultural reasons. It is not easy for non-Arab societies to acquire these skills. The Turks are a nation that later met with non-Arab Arabic. The relationship of Turks with Arabic dates back centuries. Although Turks never forget their own language, they did not use Turkish as a state language with the influence of Arab culture and civilization. In addition, the Ottomans, not only in the homeland; 
Yılmaz, H. (2019). Silsiletü'l-Lisan isimli Arapça eğitim setinin dilbilgisi öğretim yöntemi açısından değerlendirilmesi. Journal of Human Sciences, 16(3), 721-735. doi:10.14687/jhs.v16i3.5715

The school opened its doors to four corners of the empire. In almost every age of our history, Arabic has always found its place in our education system for different reasons, especially for religious reasons.

The study of Arabic textbooks is an issue that has been on the agenda for the last twentytwenty-five years. Everyone agrees that the studies are very useful for the identification of the right material and the teaching of language skills. This issue is made almost used between the years of 1992-2017 in Turkey to this day all the training sets about postgraduate studies (Özcan et al., 2015: 183). About the inin Silsiletu'l-Lisan Öğrenci education set which constitutes our working subject, the-Silsiletu'l-Lisan Set, used in Arabic Language Teaching in the Language of Bülent Ecevit University has been evaluated in a methodical way according to the views of students and teachers. A single study named Yön Solutions to Their Directions Yön (Özcan et al., 2016). In this study, the set is a study which includes the views of the students who learn Arabic between 2014-2014 at the Karakgurtar Lisan School about the design, units, exercises and language skills of the teachers. However, this study is not given the detailed information on grammar teaching and method, the main subject of this article is not a grammar teaching method, this issue is short. In this study, this set will be evaluated in terms of teaching Arabic grammar, answer to the question of whether it is sufficient or not, and the method adopted by the set in grammar education will be tried to be explained in detail.

In this study, the grammar teaching method of ral Silsiletul-Lisan lar which was prepared by the educational institution Arap el-Lisanu'l-Umm er in the United Arab Emirates, which was taught in private courses and later in the preparatory classes of the university, has been studied in our country since 2013/14 Set consists of eight books, the first two books sekiz The Beginning ", the third and the fourth book kitabi Introduction sekiz, the five and sixth books are" Intermediate c1, the seven and the eighth books are "Advanced ve.

When the flow of grammar in the set prepared with proper grammar curriculum in Turkey (Günday- Falcon, 2005: Heaping, 2005) it seems to correlate. For example; the books mentioned in the sentence start from the sentence of the third book of this set in the fifth unit of the set. In addition, as discussed in more detail in the following sections of the study, some of the subjects were not rushed to teach and the subject was kept in a simple way. In addition, as will be discussed in detail in the next section, after the fifth book, the issues begin to multiply and become heavier.

The grammar topics of the aforementioned set are considered according to the following principles:

1. Timing of the subject

2. The subject is explained in a clear way

3. Whether the subject is adequately explained

4. If there is sufficient exercise to understand the subject

5. If the processing grammar rule is sufficiently processed in the reading, listening and writing activities

In the set, it is seen that some of the subjects are processed in detail in a unit. It is seen that the training set also divides some subjects into several parts. It can be said that the set provides information that can be considered a little less for beginners. Another issue related to the method of processing the grammar issues of the set is whether the grammar rule discussed in this unit has been sufficiently processed. In another study on the set, although these grammatical issues were said to spread throughout the unit (Özcan et al., 2015: 195), this is not a very accurate approach.

In the examination, önce Silsiletu'l-Lisan sir Arabic education set has been successful in terms of grammar teaching despite some deficiencies, with the completion of the set, the subjects will be completed, the grammar activities should be increased, the reading pieces should be selected to include the grammar subjects and the basic subjects should be given before the topics In addition, it was concluded that a grammar book may have to be followed in addition to such a set. 